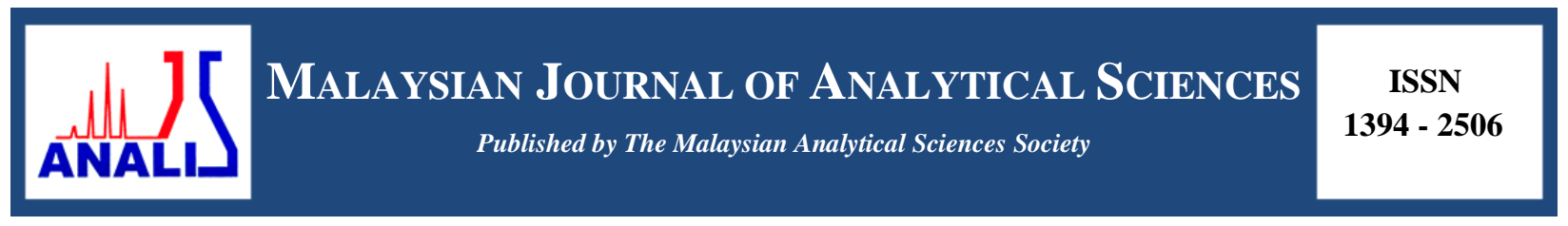

\title{
PRODUCTION OF TITANIUM DIOXIDE NANOFIBER (TNF): INFLUENCE OF ELECTROSPINNING PARAMETER ON CRYSTALLINE SIZE
}

\author{
(Penghasilan Nanogentian Titanium Dioksida (TNF): Pengaruh Parameter Elektroputaran \\ Terhadap Saiz Habluran) \\ Norulsamani Abdullah ${ }^{1}$, Siti Kartom Kamarudin ${ }^{1,2 *}$, Loh Kee Shyuan ${ }^{1}$ \\ ${ }^{l}$ Fuel Cell Institute \\ ${ }^{2}$ Department of Chemical and Process Engineering, Faculty of Engineering and Built Environment \\ Universiti Kebangsaan Malaysia, 43600 UKM Bangi, Selangor, Malaysia \\ *Corresponding author: ctie@ukm.edu.my
}

Received: 13 April 2017; Accepted: 17 April 2018

\begin{abstract}
This study aims to develop a small size of TNF using an electrospinning process. TNF is applied in direct methanol fuel cell (DMFC) as a catalyst, catalyst support and a filler in the membrane. This study involves determining the parameters that affect the electrospinning process, particularly in terms of the distance between the needle tip and collector towards the size of TNF crystalline. The production of TNF involves an electrospinning process, followed by a stabilization and calcination process. Fourier Transformation Infrared (FTIR) analysis was carried out to analyse the purity of the samples, while X-ray diffractometer (XRD) analysis was carried out to determine the size of crystalline. The result demonstrates that the longer the distance between the needle and collector, the smaller the size of the TNF produced. A smaller sized crystalline offers a significant impact on catalytic reaction and overall performance of DMFC.
\end{abstract}

Keywords: titanium dioxide, nanofiber, electrospinning, direct methanol fuel cell

\section{Abstrak}

Objektif utama kajian ini ialah membangunkan TNF bersaiz kecil untuk proses elektroputaran. Penggunaan TNF dalam sel bahan api metanol langsung (DMFC) adalah sebagai mangkin, sokongan mangkin dan pengisi di dalam membran. Kajian ini dijalankan untuk menentukan parameter yang dapat menjejaskan proses elektroputaran, iaitu jarak antara hujung jarum dan pengumpul, terhadap saiz habluran TNF. Penghasilan TNF melibatkan proses elektroputaran, diikuti dengan penstabilan dan kalsinasi. Analisis infra merah transformasi Fourier (FTIR) dijalankan untuk menganalisa ketulenan sampel, sementara analisis pembelauan sinar-X (XRD) untuk menentukan saiz habluran. Keputusan ujikaji menunjukkan semakin jauh jarak antara hujung jarum dan pengumpul, semakin kecil saiz TNF yang diperolehi. Pengurangan saiz habluran memberikan kesan yang besar kepada tindak balas pemangkinan dan prestasi keseluruhan DMFC.

Kata kunci: titanium dioksida, nanogentian, elektroputaran, sel fuel metanol langsung

\section{Introduction}

Titanium is a chemically-inert element, and the ninth-most common element found in the earth's crust [1]. Titanium dioxide $\left(\mathrm{TiO}_{2}\right)$ is among the metal oxide groups that have a wide range of applications, including cosmetics, paint, food, and catalysts and semiconductors. This study on $\mathrm{TiO}_{2}$ focuses as catalyst support in direct methanol fuel cell (DMFC) application. $\mathrm{TiO}_{2}$ consists of several types, including rutile, anatase and brookite. Each type of $\mathrm{TiO}_{2}$ has a different application. For example, for catalysts, the most suitable is the rutile type. 
The selection of a support for the nanostructures catalyst is an important factor for both catalytic activity and durability. Various combinations with different support setups have been developed by researchers, including $\mathrm{TiO}_{2}$, cerium dioxide $\left(\mathrm{CeO}_{2}\right)$, tin dioxide $\left(\mathrm{SnO}_{2}\right)$, and tungsten(VI) oxide $\left(\mathrm{WO}_{3}\right) . \mathrm{TiO}_{2}$ has especially received considerable attention, mainly because it is manufactured in small sizes, approximately in the range of $200-350$ $\mathrm{nm}$. Due to the smaller size of primary particles, $\mathrm{TiO}_{2}$ allows for the manufacture of various catalysts of enhanced activity and has a higher surface area with optimal chemical stability. The addition of $\mathrm{TiO}_{2}$ as a support catalyst can offer suitable thermal properties and dimensional stability, and the long-term life-cycle can also be improved [2]. It is a nanomaterial (ultrafine) that is used as a catalyst support in exhaust gas systems in cars, trucks and power plants, thus minimizing their overall environmental impact.

The production of $\mathrm{TiO}_{2}$ nanofiber has already been discussed in many works in the literature before using several types of techniques. The most prominent technique for producing titania nanofiber is the electrospinning technique. The processing of this nanofiber is becoming more advanced and increasing the quality of the product in various applications. Research regarding $\mathrm{TiO}_{2}$ nanofiber was initiated as early as 2003. Both Drew et al. and Li \& Xia discussed the electrospinning techniques in their work, with successful products. Drew et al. investigated the metal oxide coated with polymer nanofibers, and the size of the fibers form is around $100 \mathrm{~nm}$. Meanwhile, Li \& Xia presented nanofibers diameter in the range of 20 to $200 \mathrm{~nm}$, by varying several parameters in the electrospinning process $[3,4]$.

Madhugiri et al. applied another approach in producing $\mathrm{TiO}_{2}$ nanofibers, which is electrostatic deposition. The rutile crystal is formed during the calcination with a temperature above $800{ }^{\circ} \mathrm{C}$ [5]. Another study by Ding et al. involves synthesizing the $\mathrm{TiO}_{2}$ nanofibers, with $200-300 \mathrm{~nm}$ in diameter. The result showed that the pure titania nanofibers were obtained with high temperature calcinations [6]. The electrospinning techniques were also used by Watthanaarun et al. to produce $\mathrm{PVP} / \mathrm{TiO}_{2}$ composite nanofiber, and the diameter obtained was in the range of 120 $350 \mathrm{~nm}$. This study also investigated the effect of calcination temperature and time on size of fibers [7]. Suzuki et al. successfully produced the titania nanofibers with $20-50 \mathrm{~nm}$ in diameter by using a new technique called direct hydrothermal processing [8].

This study reported the fabrication of titanium dioxide nanofiber (TNF) via an electrospinning process. The main objective of the study is to determine the effect of electrospinning parameters, the distance between the needle tip and collector (DTC) towards the crystalline size of TNF. The TNF was prepared by the sol-gel method, followed by the electrospinning method, and a calcination process. The TNF sample was characterized by Fourier-transform infrared spectroscopy (FTIR) and X-ray diffraction (XRD) analysis. Based on the experimental results, the effect of the DTC parameter and the TNF crystalline size was discussed.

\section{Materials}

\section{Materials and Methods}

Poly(vinyl acetate), PVAc (Mw 500,000), titanium isopropoxide, TiPP, N,N-dimethylformamide, DMF, and acetic acid were obtained from Sigma-Aldrich/USA. Ethanol (99.8\%) was supplied by R\&M Chemicals. All the chemicals were directly used in this study without any further purification. The main equipment used for producing the fiber is electrospinning, from the Nfiber Electrospinning Unit.

\section{Methods}

The nanofiber was produced by using the electrospinning technique. The electrospinning solution was prepared by the sol-gel method, whereby PVAc was used as the fiber base for this experiment. The PVAc (11.5 wt.\%) was added to DMF, and stirred for 1 hour at $60{ }^{\circ} \mathrm{C}$, for 12 hours. TiPP, $50 \mathrm{wt} . \%$, and a few drops of acetic acid and ethanol were added to the polymer solution. The mixture was homogenized in a homogenizer for 2 minutes. The solution was then transferred to a syringe and the solution was injected in the electrospinning by applying a high voltage of $16 \mathrm{kV}$ with $0.5 \mathrm{~mL} / \mathrm{h}$ for the flowrate, and different distances between the tip of needle and the collector. The fiber was then stabilized in the oven for 8 hours, at $130{ }^{\circ} \mathrm{C}$. The stabilized fiber underwent a calcination process in the furnace for $850{ }^{\circ} \mathrm{C}$, and the powder size was normalized using a mortar and pestle. The purity of the TNF was analysed using FTIR analysis, while the structure and crystalline size of the sample underwent XRD analysis. 


\section{Results and Discussion}

Figure 1 illustrates the existence of the functional group in the TNF sample from FTIR analysis. The sample is denoted by TNF (distance (cm)), TNF 12, TNF 13, TNF 14, TNF 15, TNF 16. The graph shows that all samples have functional group O-Ti-O, which appears in the wavenumber range of $450 \mathrm{~cm}^{-1}$ to $700 \mathrm{~cm}^{-1}$ [6]. The purity of the sample is proven from the FTIR analysis, where all other functional groups do not appear in the graph of the sample. Other solvents and chemical compounds were completely removed during the calcination process. The different parameters of electrospinning do not offer a significant impact on the functional group of the sample.

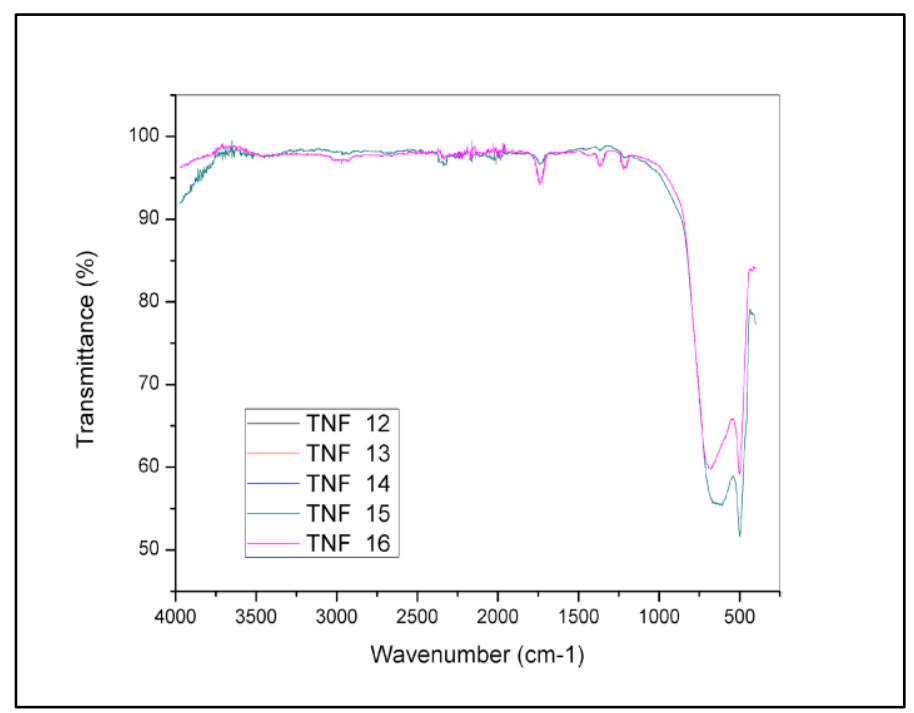

Figure 1. FTIR analysis of TNF sample after calcination process at $850{ }^{\circ} \mathrm{C}$ for 2 hours

Figure 2 presents the XRD pattern for the TNF sample with various distances between the needle tip and the collector. The result shows that the TNF structure exists in the rutile form, due to the high temperature used during the calcination process at $850{ }^{\circ} \mathrm{C}$ for 2 hours. There was almost no influence on the different distances during the preparation of nanofiber towards the crystal structure of TNF. XRD pattern for TNF sample shows the crystallographic tetragonal structure: related to the rutile structure form. The crystalline size was calculated using Debye-Scherrer equation (refer equation 1)[9], which needs data from the XRD analysis for the peak position of $\mathrm{TiO}_{2}(110)$ :

$$
\text { Crystalline size }=0.98 \alpha / \beta \cos \theta
$$

where $\alpha$ represents the wavelength of the X-ray, $\theta$ represents the angle at the peak, and $\beta$ represents the width of the peak at half height. The crystalline size can also be determined from the XRD analysis using Eva software. It was calculated based on the Debye-Scherrer equation. The crystalline size for all samples is tabulated in Table 1. 
Norulsamani et al: PRODUCTION OF TITANIUM DIOXIDE NANOFIBER (TNF): INFLUENCE OF

ELECTROSPINNING PARAMETER ON CRYSTALLINE SIZE

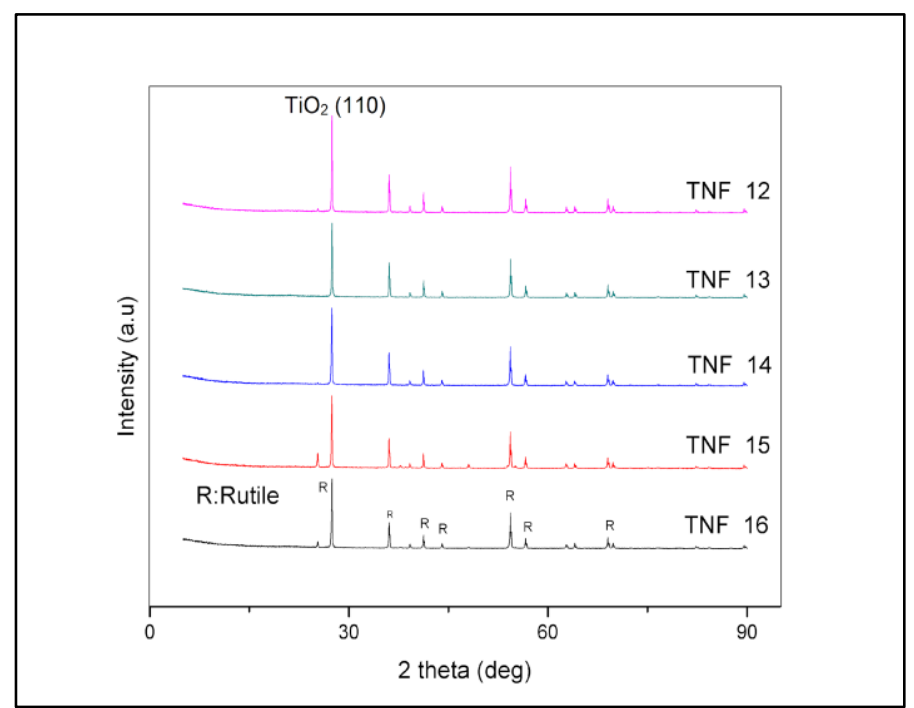

Figure 2. XRD patterns for TNF sample

Table 1. Calculated crystalline size from XRD analysis

\begin{tabular}{lcc}
\hline Sample & $\begin{array}{c}\text { FWHM } \\
\left({ }^{\mathbf{}}\right)\end{array}$ & $\begin{array}{c}\text { Crystalline size } \\
(\mathbf{n m})\end{array}$ \\
\hline TNF 12 & 0.066 & 12.33 \\
TNF 13 & 0.0704 & 11.55 \\
TNF 14 & 0.0749 & 10.86 \\
TNF 15 & 0.0799 & 10.18 \\
TNF 16 & 0.0817 & 9.96 \\
\hline
\end{tabular}

The smallest crystalline size of TNF, $9.96 \mathrm{~nm}$, was calculated at the distance of $16 \mathrm{~cm}$ between the needle tip and the collector. The result also shows that, the higher the distance, the smaller the crystalline size produced. This is because of several technical and mechanical situations that occurred during the electrospinning process, namely, high voltage applied to the tip of the needle, and the electrical force makes the solution of TNF deformed from the shape caused by the surface tension alone, and forms Taylor cone. As the electrical field reaches critical values, the TNF solution overcomes its surface tension and viscoelastic force, resulting in the jet of solution in bending, winding and spiralling path towards the collector. This phenomenon is known as bending instability, which is the dominant thinning mechanism in electrospinning [10]. Figure 3 shows a detailed illustration of this phenomenon.

Next, the distances take place in process to produce the smallest size of TNF. The remote distance causes the bending instability phenomena to reoccur, increasing the loop circumference and producing thinner and smaller nanofibers on the collector. The distance also represents the area of the electric field involved in the electrospinning process. The changes in distance can change the morphological properties of the nanofiber, either for crystalline size, diameter, or bead density, and produce a variety shapes on the surface [11]. 


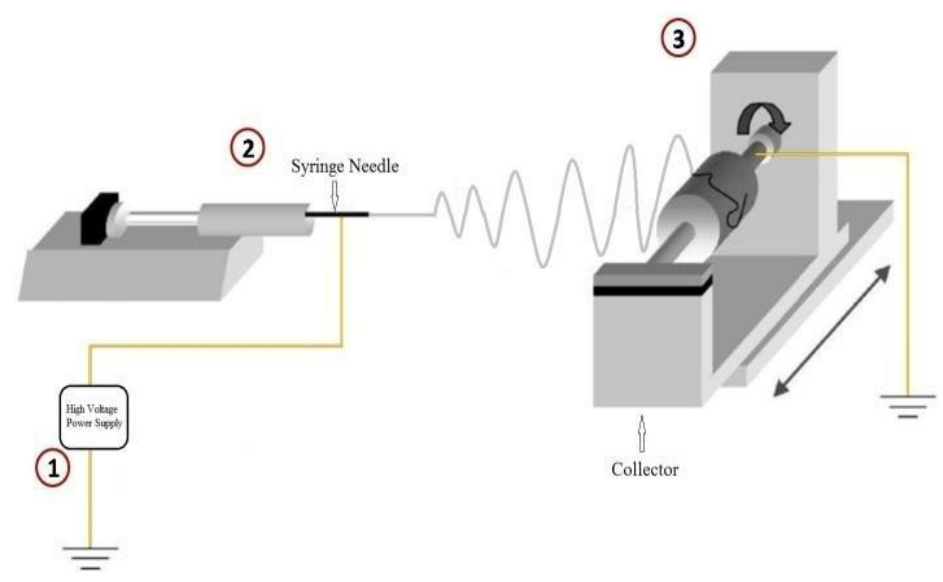

Figure 3. Illustration of dominant thinning mechanism

\section{Conclusion}

Finally, this study successfully produced TNF using electrospinning. The results show that the smaller crystalline size is an important factor to increase the active catalytic surface area. The electrospinning parameter has an effect on the size of the TNF, and one of the parameters involved is the distance between the needle tip and collector. The XRD result shows that the higher the distance, the smaller the crystalline size of TNF. The smallest crystalline size of $9.96 \mathrm{~nm}$ was obtained for the $16 \mathrm{~cm}$ distance between the needle tip and collector. This shows that the parameter of the electrospinning successfully produces a suitable size for the sample.

\section{Acknowledgement}

The authors gratefully acknowledge the financial support given for this work by Universiti Kebangsaan Malaysia (UKM) under DIP-2015-002.

\section{References}

1. Abdullah, N. and Kamarudin, S. (2015). Titanium dioxide in fuel cell technology: An overview. Journal of Power Sources, 278: 109 - 118.

2. Mallakpour, S., Zhiani, M., Barati, A. and Rostami, H. (2013). Improving the direct methanol fuel cell performance withpoly(vinyl alcohol)/titanium dioxide nanocomposites as a novel electrolyte additive. International Journal of Hydrogen Energy, 38(28): 12418 - 12426.

3. Drew, C., Liu, X., Ziegler, D., Wang, X., Bruno, F. F., Whitten, J. and Kumar, J. (2003). Metal oxide-coated polymer nanofibers. Nano Letters, 3(2): 143 - 147.

4. Li, D. and Xia, Y. (2003). Fabrication of titania nanofibers by electrospinning. Nano Letters, $3(4)$ : 555 - 560.

5. Madhugiri, S., Sun, B., Smirniotis, P. G., Ferraris, J. P. and Balkus, K. J. (2004). Electrospun mesoporous titanium dioxide fibers. Microporous and Mesoporous Materials, 69(1): 77 - 83.

6. Ding, B., Kim, C. K., Kim, H. Y., Seo, M. K. and Park, S. J. (2004). Titanium dioxide nanofibers prepared by using electrospinning method. Fibers and Polymers, 5 (2): 105 - 109.

7. Watthanaarun, J., Pavarajarn, V. and Supaphol, P. (2005). Titanium(IV) oxide nanofibers by combined sol-gel and electrospinning techniques: preliminary report on effects of preparation conditions and secondary metal dopant. Science and Technology of Advanced Materials, 6(3): 240 - 245.

8. Suzuki, Y., Pavasupree, S., Yoshikawa, S. and Kawahata, R. (2005). Natural rutile-derived titanate nanofibers prepared by direct hydrothermal processing. Journal of Materials Research, 20(04): 1063 - 1070.

9. Ito, Y., Takeuchi, T., Tsujiguchi, T., Abdelkareem, M. A. and Nakagawa, N. (2013). Ultrahigh methanol electro-oxidation activity of $\mathrm{PtRu}$ nanoparticles prepared on $\mathrm{TiO}_{2} /$-embedded carbon nanofiber support. Journal of Power Sources, 242: 280 - 288.

10. Zhang, L., Aboagye, A., Kelkar, A., Lai, C., and Fong, H. (2014). A review: Carbon nanofibers from electrospun polyacrylonitrile and their applications. Journal of Materials Science, 49(2): 463 - 480.

11. Chronakis, I. S. (2005). Novel nanocomposites and nanoceramics based on polymer nanofibers using electrospinning process - a review. Journal of Materials Processing Technology, 167(2): 283 - 293. 